\title{
A CENSURA MUSICAL DURANTE O REGIME MILITAR (1964-1985)
}

\author{
Music censorship during the military regime \\ (1964-1985)
}

Maika Lois Carocha*

Para O ESTADÃO

Está na praça, já chegou

$O$ dicionário do censor

Desde A até Z

Tem o que você pode ou não pode dizer

Antes de pôr no papel

O que você pensou

Veja se na sua frase

Tem uma palavra que não pode

Substitua por uma que pode

Você não queria assim...mas que jeito?

O dicionário do censor

É que decide, não o autor

Um exemplo pra você

Se na página do " $p$ "

Não consta a palavra "povo"

É porque esta não pode

Vê se no "o" tem escrito "ovo"

Ovo pode...

Se o sentido não couber esqueça, risque tudo, compositor

Seu dever é decorar

As que pode musicar

No dicionário da censura Nem botaram “dentadura”...

Raul Seixas

* Mestranda do Programa de Pós-Graduação em História Social (PPGHIS) da Universidade Federal do Rio de Janeiro (UFRJ) e pesquisadora do Grupo de Estudos sobre a Ditadura Militar (IFCS/ UFRJ). 


\begin{abstract}
RESUMO
Durante os anos 1970, a música popular brasileira teve seu período de maior crescimento. Este fato certamente não passou despercebido pelos sucessivos governos militares, que durante todo o período de vigência do regime estiveram atentos ao que era produzido na esfera musical. Este artigo tem por objetivo empreender uma análise da censura musical. Esta esteve inserida na censura de diversões públicas e articulada no âmbito da tradição, que sempre amparou a censura dos costumes, enveredada em torno de valores morais conservadores ligados, sobretudo, à ética cristã.
\end{abstract}

Palavras-chave: ditadura militar; censura; música; repressão cultural.

\begin{abstract}
During the 1970s, Brazilian popular music had a period of growth. This fact certainly wasn't unnoticed by the successive military governments, which were attentive to what was produced in the musical space during all the period of that political system. This article analyses the musical censorship, which was inserted in public entertainment and articulated with traditional entertainment censorship in Brazil. This censorship was supported by the traditional moral conservative values connected to Christian ethics.
\end{abstract}

Key-words: military dictatorship; censure; music; cultural repression.

No Brasil, a música popular, provavelmente mais do que qualquer outra manifestação cultural, por sua penetração indubitável na camada média urbana da população, teve papel fundamental na formação de uma identidade nacional. A introdução do sistema elétrico de gravação, já em 1927, proporcionou um enorme alcance deste tipo de manifestação cultural. ${ }^{1}$ Entretanto, foi nos anos 1970, com o processo de consolidação da indústria fonográfica e da televisão, que a música teve seu período de maior crescimento. O caráter de socialização trazido pela indústria cultural no sentido da divulgação das músicas, aliado à massificação da televisão, fez com que a música se tornasse presença constante na vida dos habitantes das grandes cidades, sendo um veículo de manifestação bastante utilizado. Como pode-

1 CABRAL, Sérgio. ABC do Sérgio Cabral: um desfile dos craques da M.P.B. Rio de Janeiro: Codecri, 1979. p. 36. 
mos perceber, graças à significativa importância da indústria fonográfica e à forte capacidade de influência da música nas grandes metrópoles brasileiras, o regime militar não pôde deixar de voltar as suas atenções para este tipo de manifestação cultural.

Neste artigo, vamos esmiuçar os trâmites da censura musical durante o regime militar para que possamos entender seu modo de funcionamento e as principais motivações para esse tipo de censura.

Vigiados com atenção pelo regime militar, a MPB, o samba e o rock acabaram formando uma espécie de frente ampla contra a ditadura, cada qual desenvolvendo um tipo de crítica, atitude e crônica social que forneceram referências diversas para a idéia de resistência cultural. A MPB com suas letras engajadas e elaboradas, o samba com a sua capacidade de expressar uma vertente da cultura popular urbana ameaçada pela modernização conservadora capitalista, e o rock com seu apelo a novos comportamentos e liberdades para o jovem das grandes cidades. Não foi por acaso que ocorreram muitas parcerias, de shows e discos, entre os artistas dos três gêneros.

A televisão, que ao longo dos anos 1950 permaneceu como novidade, extravagância, acessível apenas às faixas mais ricas da população das grandes cidades brasileiras, foi pouco a pouco aumentando a sua faixa de alcance. Desde 1962, com a introdução do videotape (que permitia gravar, editar e reproduzir programas, até então feitos ao vivo), a televisão ganhou novos recursos e aprimorou seu aparato tecnológico de produção e transmissão de programas. O barateamento dos processos de transmissão e produção de programas possibilitou a criação de uma gama mais variada de atrações, que, aliada à crescente queda do preço dos aparelhos televisivos, permitiu que já no ano de 1968 a TV pudesse ser considerada um veículo de massas, disputando com o rádio o papel de principal meio de comunicação de massa nas grandes cidades brasileiras:

Essa mudança nos padrões de audiência e o surgimento de novas fórmulas de programas foram acompanhadas por um salto nos números dos aparelhos de TV, durante 1967. Entre janeiro de 1966 e janeiro de 1967 o número de unidades familiares aumentou de 633.156 para 698.065 , registrando $10 \%$ de acréscimo. Entre janeiro de 1967 e janeiro de 1968, o aumento foi de quase 35\%, totalizando 959.221 unidades familiares, só 
no Estado de São Paulo. Além disso, o acesso das classes mais pobres ao aparelho cresceu no montante geral. Mas foi em 1968 que a TV passou a ser, não só mais disseminada na sociedade numericamente falando, mas também sensivelmente mais “popular”. Outra estatística esclarecedora demonstra que entre 1965 e 1967 a média anual de vendas de aparelhos de TV oscilou entre 10 e 15\%. Somente de 1967 para 1968, as vendas aumentaram $45 \%$. $^{2}$

Desde o início de suas atividades, ainda na década de 1950, as emissoras de televisão (inicialmente apenas a TV Tupi e a TV Record de São Paulo) dedicaram-se aos programas musicais. Com o aumento da amplitude social desse tipo de mídia, a música ganhou um espaço cada vez maior. A relação entre música e TV consolidou a mudança do lugar social da canção iniciado com o advento da Bossa Nova e incrementou o panorama musical brasileiro, principalmente do ponto de vista mercadológico. A divulgação da música, tomando como exemplo a Bossa Nova, até então ocorria em circuitos fechados, como o circuito universitário. O papel de centro gerador do mercado musical brasileiro que esse circuito possuía foi deslocado para a televisão, ampliando a audiência da música brasileira em todas as faixas sociais, na medida em que a TV era um fenômeno que abrangia segmentos bem mais amplos.

A popularização da televisão levou consigo a música, ao lado das telenovelas, um de seus principais produtos. Este fenômeno atingiu diretamente o mercado fonográfico brasileiro. Paralelamente, o panorama fonográfico brasileiro sofreu uma grande mudança institucional e de mercado, ao longo dos anos 1960:

Em 1965, as gravadoras formaram a ABPD (Associação Brasileira de Produtores de Disco), visando uma atuação corporativa junto ao poder público. As duas conseqüências imediatas foram: a Lei de incentivos fiscais de 1967 (que permitiu aplicar o ICM devido pelos discos internacionais em

2 Boletim de Assistência de TV (São Paulo), Ibope apud NAPOLITANO, Marcos. Seguindo a canção: engajamento político e indústria cultural na MPB (1959-1969). São Paulo: Annablume: Fapesp, 2001. p. 103. 
discos nacionais) e a nova Lei de Direitos Autorais (em 1979), que permitiu, por exemplo, a não numeração de discos produzidos. Paralelamente a estas mudanças institucionais, ocorreu uma profunda mudança na estrutura do mercado: em 1959, em cada 10 títulos comprados 7 eram estrangeiros. Em 1969, esta relação se inverte nas mesmas proporções. ${ }^{3}$

Como podemos verificar pela relação de títulos comprados nos anos de 1959 e 1969, houve um nítido processo de "substituição de importações”, o mercado brasileiro passou a consumir canções compostas, interpretadas e produzidas no próprio país. Se o LP foi o suporte técnico que permitiu consolidar um elenco fixo de compositores e intérpretes (cuja realização comercial era mais garantida do que a antiga fragmentação de intérpretes dependentes de compositores), os programas musicais da TV e, sobretudo, os festivais da canção veiculados pela TV foram os veículos apropriados para apresentar novos artistas e obras perante um público amplo e heterogêneo.

No final de 1968 e início de 1969 esse panorama sofreu uma nova transformação, quando a indústria do disco já possuía capital institucional suficientemente grande para iniciar um processo de ocupação do lugar da televisão na definição dos rumos do panorama de consumo musical. A indústria do disco caminhava para uma nova racionalidade produtiva, em direção a um maior planejamento e estandardização de seus produtos, características de uma indústria cultural já consolidada, processo que só em meados dos anos 1970 seria acompanhado pela televisão. ${ }^{4}$

O outro pólo da relação regime militar - censura musical eram os cantores e compositores que tiveram suas composições vetadas na íntegra ou parcialmente cortadas. Alguns deles desenvolveram mecanismos muitos específicos tentando sempre driblar a censura. O uso de figuras de linguagem, metáforas, invenção de palavras, inserção de barulhos como buzinas, batidas de carros, dentre outros, ou a supressão total da melodia no momento em que deveria aparecer a frase ou palavra censurada eram largamente utilizados por aqueles que estavam preocupados em transmitir sua mensa-

3 NAPOLITANO, Marcos, op. cit., p. 83.

4 Entre os anos de 1966 e 1976, a indústria fonográfica cresceu cerca de 444\%, contra 152\% do PIB no mesmo período (PAIANO, 1994, p. 195-196). 
gem para o público, mesmo de forma sutil. Para estes compositores e cantores, segundo Gilberto Vasconcellos,

O importante é saber como pronunciar; daí a necessidade do olho na fresta da MPB. Contudo, não basta somente retina. Além de depositar certa confiança na argúcia do ouvido musical, a metáfora da fresta contém uma aporia: restam ainda os percalços objetivos da decodificação. ${ }^{5}$

Na "linguagem da fresta”, as letras das músicas faziam sentido não no dito, mas no interdito, nas entrelinhas. Houve um outro grupo de cantores e compositores que também estiveram preocupados em burlar a censura. Mas com outra técnica, que não a "linguagem da fresta". Enveredaram pelos caminhos do chamado “desbunde”, expressão utilizada para designar na MPB as canções cujas letras se fizeram a partir de uma utopia não localizada no tempo ou no espaço, com "viagens”, "portos”, “cais”, "partidas”, "trens”, “estações” ou "festas”, "brincadeiras”, “carnavais”, etc. Assim, tentaram fazer com que o público assimilasse sua proposta de novos valores para uma nova sociedade. ${ }^{6}$

Mesmo com a utilização de todos estes recursos estilísticos, a situação da música brasileira nos anos 1970 e 1980 foi complexa. Diversos artistas estavam morando fora do país, em exílios voluntários ou forçados. Os compositores viram-se pressionados pelo aparelho repressivo do regime autoritário, e a grande maioria, mais diretamente, pela censura. Esta passou a ser condição sine qua non para a realização de seus trabalhos. Em uma entrevista, no ano de 1971, do compositor Chico Buarque de Hollanda podemos perceber claramente como a censura pressionava seu trabalho:

É claro que cheguei à autocensura. Mas, dentro deste limite que já me coloquei, eu acho que ainda tenho campo para fazer este negócio. Este tipo de música que tenho feito, que para mim é uma coisa nova, é a razão de eu fazer um disco novo.

5 VASCONCELLOS, Gilberto. Música popular: de olho na fresta. Rio de Janeiro: Graal, 1977. p. 72.

6 GARCIA, Eduardo Amorim. Canto curtido: a MPB nos anos 70. Revista do Brasil, n. 4, p. $60-80$, [s.d.]. 
Elas estão dentro de limites que, eu acho, no espírito da censura, podem passar. Agora, se eles me fizerem recuar mais, eu paro. ${ }^{7}$

A censura musical inserida no âmbito da moral e dos bons costumes não foi criada pelo regime militar, desde o Estado Novo "a censura prévia vigiava de perto a música popular, canções de teor político só eram divulgadas pelo rádio quando elogiosas ao Estado", ${ }^{8}$ mas foi sendo adaptada paulatinamente às especificidades do período em questão.A censura musical e todas as outras que fizeram parte do conjunto conhecido por diversões públicas eram feitas previamente, o que conferiu ao processo censório uma grande capacidade de coerção. ${ }^{9}$ A censura prévia era uma atividade legal do Estado desde a Constituição de 1934 - que introduziu no sistema jurídico a censura prévia aos espetáculos de diversões públicas. A Constituição de 1937 aumentou a área de atuação da censura, incluindo a radiodifusão. A Constituição de 1946 ratificou os ditames acerca da censura que já existiam na Constituição de 1937. A partir de 1965, uma nova legislação censória foi sendo construída pelo regime militar, aproveitando muitos artigos já existentes e criando novos mecanismos que melhor atendessem às suas necessidades coercitivas. A ação censória, institucionalizada em códigos e leis, foi orientada no sentido de preservar a moral vigente e o poder constituído.

Em um primeiro momento, a censura de diversões públicas foi marcada por uma atuação multifacetada, tendo o seu funcionamento apenas regional..$^{10}$ Essa característica foi sendo alterada por causa da construção de uma legislação que adaptou a censura às necessidades do novo regime.

Em 1965, com a inauguração do novo prédio do Departamento Federal de Segurança Pública (DFSP), no Distrito Federal, teve início o processo de centralização da atuação censória no Serviço de Censura de

7 REVISTA VEJA, 15 set. de 1971, p. 3, grifo meu.

8 MOBY, Alberto. Sinal fechado: a música popular brasileira sob censura. Rio de Janeiro: Obra Aberta, 1994. p. 105.

9 A expressão “diversões públicas” compreendia música, teatro, televisão, cinema, programação radiofônica e atividades circenses.

10 Em 1961, o então Presidente Jânio Quadros, atendendo às reivindicações de setores conservadores, em especial entidades católicas, assinou o Decreto n. 50.518, que concedeu aos estados federativos o direito de exercer censura. 
Diversões Públicas do Departamento Federal de Segurança Pública (posteriormente Departamento de Polícia Federal), em detrimento das censuras regionais. Com o Decreto n. 43, de 1966, que estabeleceu a exclusividade da União para a execução da censura, o processo de centralização foi intensificado. $^{11}$

A necessidade de uma atuação censória mais centralizada se fez sentir no interior dos próprios órgãos censórios logo no início do regime. Em um ofício datado de 12 de maio de1964, enviado pelo chefe do então Serviço de Censura de Diversões Públicas (SCDP), Edísio Gomes de Matos, ao chefe de polícia do DPSP, foi realizada uma espécie de estudo acerca das leis que regiam a censura no Brasil. Analisando a legislação censória desde 1939, o chefe da censura sugeriu diversas adaptações. Para ele, entretanto,

já não [importava], hoje em dia, que essa repartição pertença ou não à polícia, o que efetivamente importava é estruturá-la em moldes compatíveis com os anseios de progresso e de desenvolvimento do país. Creio por isso, haver chegado o momento de dar solução adequada a um problema que, não sendo dos mais graves, mas de significativa importância para o país, eis que é definir o papel da censura. O primeiro passo deverá ser a centralização uma única instância que será a única responsável pela feitura dos diversos tipos de censura de diversões públicas: do cinema ao teatro. ${ }^{12}$

Antes que as alterações requeridas fossem atendidas, ele sugeriu a manutenção da legislação em vigor, pois,

enquanto não for baixado o regulamento do Serviço Federal de Censura e o Código Brasileiro de Diversões Públicas, permanecerão em vigor os Decretos n. 20.493, de 24 de janeiro

11 Decreto n. 43 de 18 de novembro de 1966. Cria o Instituto Nacional de Cinema, torna de competência exclusiva da União a censura e dá outras providências.

12 Fundo “Divisão de Censura de Diversões Públicas” Arquivo Nacional, Coordenação Regional do Arquivo Nacional no Distrito Federal, Série "Correspondência oficial”, Subsérie "Ofícios de comunicação”, Ofício n. 391/64-SCDP, datado de 12 de maio de 1964. p. 4. Caixa 1. Doravante mencionaremos apenas a série, o título do documento e a sua localização. 
de 1946, e 30.008, de 8 de março de 1955, naquilo que não colidir com as presentes disposições. ${ }^{13}$

Mesmo no momento inicial do regime, a censura necessitava de urgentes adaptações não apenas no que concernia à questão da centralização, mas também em relação à regulamentação de outros pontos, como, por exemplo, aqueles referentes à profissionalização e uniformização da censura.

Com a centralização da censura em Brasília no ano de 1966, a Divisão de Censura de Diversões Públicas (DCDP), subordinada ao Departamento Federal de Segurança Pública (DFSP), passou a ser o órgão responsável pela censura de diversões no país. Este processo de centralização foi fundamental para a censura, pois esta pretendia ter uma atuação mais coerente e uniforme. De algum modo, também simplificou a vida dos artistas, produtores e distribuidores, que agora requeriam uma única liberação, válida para todo o país. Entretanto, a oficialização da centralização da censura ocorreu apenas em 1967, com a outorga da Constituição daquele ano. ${ }^{14}$

Embora a centralização fosse uma demanda dos próprios órgãos censórios e regulamentada por lei federal, o processo certamente não foi tranqüilo. Muitos chefes de censuras regionais alegaram que a centralização traria problemas. O coronel Waldemar Bianco, chefe da censura no Paraná em 1968, não se conformava em ter de "acatar decisões do planalto central”, pois "há coisas que servem para a Guanabara e São Paulo, mas não servem para o Paraná”. O coronel e 15 censores foram a Brasília para obter o direito de julgar o teatro "sob um ponto de vista paranaense". ${ }^{15}$

Em 1972, seis anos após a centralização, ainda surgiam problemas entre as censuras regionais e a central. O diretor da DCDP, Rogério Nunes, encaminhou um ofício extraordinário ao juiz federal da Segunda Vara do Estado de São Paulo explicando a urgência na censura de um compacto que tinha apenas uma música de autoria de Paulo Sérgio Valle e Marcos Valle intitulada Hermoza. A urgência decorreu da liberação da mesma

13 Ibid., p. 3.

14 STEPHANOU, Alexandre Ayub. Censura no regime militar e militarização das artes. Porto Alegre: Edipucrs, 2001. p. 270.

15 REVISTA VEJA, n. 6, 16 out. 1968, p. 22. 
composição pelo SCDP/Guanabara sem a devida análise da censura federal:

Em atenção ao ofício expedido por este respeitável juízo sob o número 276/72, são requisitadas informações para a instrução do mandato de segurança impetrado por Paulo Sérgio Valle, que aponta como ilegal a decisão da Divisão de Censura de Diversões Públicas, que resultou na apreensão de seu compacto intitulado Hermoza. ${ }^{16}$

Em resposta à solicitação do diretor da DCDP, alegou o juiz federal da segunda vara

ser o mandato legal, na medida em que Paulo Sérgio Valle impetrou o mandato de segurança devido a principal razão da música Hermoza, que compõe o compacto de mesmo nome, já ter recebido certificado de liberação no SCDP do Estado da Guanabara e sendo esta a única música do compacto não haveria razão para uma censura daquilo que já havia sido liberado, palavras do advogado do compositor. ${ }^{17}$

Razões ideológicas à parte, o que determinou este tipo de situação foi o fato de as censuras regionais não quererem perder seu poder de censurar independentemente da opinião da censura federal. Como a censura federal ficava muito isolada em Brasília, não foi possível desativar completamente as censuras regionais porque estas eram responsáveis diretas pela fiscalização da programação musical de bares, concertos, festivais e shows nos seus estados.

Este tipo de disputa permaneceu até o fim da censura de diversões públicas. Em 1980, ocorreu um caso muito ilustrativo desta tensão permanente entre as censuras. A liberação da peça teatral de Chico Buarque intitulada A ópera do malandro com a impropriedade de 18 anos acabou

16 Série “Correspondência oficial”, Subsérie “Ofícios de comunicação”, ofício n. 276/72, datado de 24 de julho de 1972. p. 2. Caixa 1.

17 Ibid., p. 6. 
por criar uma situação embaraçosa entre os SCDPs do Rio de Janeiro e de São Paulo e a DCDP. A peça teatral foi liberada no Rio de Janeiro e, valendo-se desta liberação, a gravadora Polygram Discos deu entrada no requerimento para a liberação, das letras musicais na censura paulista. A empresa, intencionalmente, solicitou a liberação da trilha musical de todo o espetáculo e obteve o certificado de liberação para a gravação de um LP com as músicas da referida peça. Entretanto, a DCDP solicitou uma análise de cada música separadamente e acabou por vetar a composição Geny e o zepelin, determinando a supressão desta música do LP. Esta ordem gerou polêmica no SCDP/SR/SP, já que contrariava uma decisão tomada anteriormente por este órgão. Nas palavras do diretor da DCDP, José Vieira Madeira,

deveria o técnico da censura, encarregado do exame, em São Paulo, ter tido o cuidado de solicitar mais documentos. Entretanto, o sistema de aprovação de letras musicais vinha demonstrando falhas face a sua descentralização, fato esse que será agora corrigido com a centralização completa na sede da DCDP, evitando-se burlas como essa, em que não se pode responsabilizar somente o técnico de censura, mas toda a estrutura em utilização. ${ }^{18}$

A resposta vinda de São Paulo foi enérgica:

Em instruções dadas pelo Exmo. Ministro da Justiça já foram estabelecidos os critérios para a liberação de letras musicais, que são claros em afirmar que os respectivos requerentes do certificado de liberação podem dar entrada através dos órgãos censórios das delegacias e subdelegacias regionais, representantes da Polícia Federal nos estados. ${ }^{19}$

Para a surpresa das censuras regionais, e principalmente para o deleite do público consumidor de LPs, a DCDP acabou por liberar todo o LP A ópera do malandro, dois meses após o início do processo na sua sede. ${ }^{20}$

18 Série "Censura prévia”, Subsérie "Música”, processo n. 03/80-SO/DCDP, datado de 8 de janeiro de 1980. p. 1. Caixa 718.

19 Ibid., p. 42 da pasta em anexo. Caixa 718.

20 Ibid., telex n. 451/80/DCDP, anexado ao processo n. 03/80-SO/DCDP. Caixa 718. 
Este tipo de situação de conflito foi bastante usual, por mais que se expedissem leis asseguradoras de uma unidade para a censura. ${ }^{21}$ Um exemplo é o Decreto n. 56.510, de junho de 1965, que em seu artigo 176 versou sobre a unificação dos critérios para a liberação das letras musicais. Ficou decretado que as letras de músicas seriam censuradas exclusivamente em Brasília, o requerente de censura seria o autor ou seu outorgante, devendo anexar original e duas cópias carbônicas sem borrão ou rasura. O prazo para o exame da letra era de 30 dias. $^{22}$ A lei era clara. Entretanto, como pudemos ver no processo referente ao LP A ópera do malandro, nem sempre a interpretação foi tão simples assim. Uma ordem de serviço expedida pelo Ministério da Justiça no ano de 1968 e direcionada ao Serviço de Censura de Diversões Públicas da Guanabara buscava exclusivamente esclarecer o Decreto n. 56.510. ${ }^{23}$ Dois anos após esta ordem de serviço, uma outra, partindo também do Ministério da Justiça e seguindo o mesmo tom, era expedida. O que nos mostra que o entendimento desse decreto, principalmente do artigo que versava sobre o fato de as letras musicais serem censuradas exclusivamente em Brasília, fora comprometido. ${ }^{24}$ Os próprios relatórios anuais de atividades emitidos pela DCDP listavam as letras de músicas censuradas separadamente, ou seja, as músicas censuradas em Brasília e nas SCDPs regionais, o que demonstra que a censura não era realizada exclusivamente na DCDP. ${ }^{25}$

A censura de diversões públicas foi apenas um dos componentes do aparelho repressivo montado pela ditadura militar com o intuito de garantir a sua legitimação no interior da própria corporação militar e perante o restante da sociedade civil. Com a circulação de um discurso ético-moral que permeou todo esse aparelho repressivo, tentou garantir a aceitação dos

21 Só no ano de 1979 pudemos ver sete processos com resultados conflitantes entre a DCDP e as SCDP regionais. Série “Censura prévia”, Subsérie “Música”, processos n. 154/37/79, n. 1278-45/79, n. 03/80/79, n. 4589/79, n. 116101/79, n. 083445/DCDP e n. 1307/79 nas Caixas 718, 725 e 644, respectivamente.

22 CENSURA FEDERAL (conjunto de leis). Brasília: Editor Carlos Rodrigues, 1971. p. 159.

23 Série “Correspondência oficial”, Subsérie “Ofícios de comunicação”, ordem de serviço n. 22/68-SCDP. Caixa 2.

24 Ibid., ordem de serviço n. 456/70-DCDP. Caixa 4.

25 Série “Correspondência oficial”, Subsérie “Ofícios de comunicação”, "Relação das letras musicais proibidas pelos órgãos da Censura Federal no período de 1 de setembro a 31 de dezembro de 1972”, sem numeração. Caixa 1. 
atos praticados pelo regime. Esse aparelho repressivo, além da censura de diversões públicas, abrangeu também a propaganda política, a censura à imprensa escrita, a espionagem e a polícia política. ${ }^{26}$

O regime militar brasileiro, tendo em vista a ausência de legitimidade política, tentou suprir essa deficiência com a montagem do aparelho repressivo e também a partir de dois aspectos que, inclusive, o diferenciaram das demais ditaduras latino-americanas e o tornaram peculiar: a contínua rotatividade dos generais-presidentes no poder, de modo a evitar o desgaste de uma ditadura personalista; e, por outro lado, a estruturação de toda uma "teia legal" constituída de decretos, decretos-lei, atos institucionais, atos complementares, etc., que conferiram aos chefes militares, durante longo período, a possibilidade do cometimento das maiores arbitrariedades, pois praticamente anularam o Poder Legislativo, enquadraram o Judiciário e deram ao Executivo a possibilidade de silenciar a oposição. ${ }^{27}$

Sendo a censura de diversões públicas uma parte do aparelho repressivo montado pelo regime militar, nada mais natural que houvesse uma comunicação entre as diferentes instâncias que formavam esse aparelho. As turmas de censores responsáveis pela análise das letras musicais não hesitavam em solicitar dossiês de artistas aos Dops e, por outro lado, o Dops mantinha-se usualmente em contato com a DCDP e as SCDPs regionais para a troca de toda sorte de informações. ${ }^{28}$

Determinados artistas, especialmente aqueles que tiveram as suas letras muito visadas pela censura, eram monitorados pelos Dops, que enviavam relatórios bimestrais à DCDP. ${ }^{29}$

O cantor e compositor Sérgio Ricardo teve inúmeras músicas proibidas ou mutiladas pela censura. Suas composições eram perpassadas por

26 FICO, Carlos. Espionagem, polícia política, censura e propaganda: os pilares básicos da repressão In: FERREIRA, Jorge; DELGADO, Lucilia Almeida Neves (Orgs.). O Brasil Republicano: o tempo da ditadura - regime militar e movimentos sociais em fins do século XX. Rio de Janeiro: Civilização brasileira, 2003.

27 SOARES, Gláucio Ary Dillon. A política de cassações. Revista Dados, Rio de Janeiro, n. 21, p. 65-85, 1979.

28 Os Dops (Delegacias de Ordem Política e Social) eram formadores da polícia política juntamente com o sistema Codi-DOI (Centro de Operações de Defesa Interna - Destacamento de Operações de informações) que integravam um sistema de segurança maior: o Sissegin (Sistema de Segurança Interna).

29 Série “Correspondência oficial”, Subsérie “Ofícios de comunicação”, "Relação de correspondência da Censura Federal no período de 1 de janeiro a 31 de dezembro de 1972”, sem numeração. Caixa 1. 
um viés eminentemente político. A preocupação da censura com o compositor era tanta que, no ano de 1968, foi solicitada sua ficha ao DOPS. Como o cantor não era fichado, foi feita a seguinte sugestão:

Comunico a Vossa Excelência que nesta data estou encaminhando ofício ao senhor Delegado Regional de São Paulo, solicitando providências no sentido que o compositor Sérgio Ricardo seja fichado no S.O.P.S face as suas atividades subversivas, ao compor músicas com mensagem contrária aos interesses nacionais. Junto ao presente encaminhamento das letras musicais deste compositor vetadas pela censura. ${ }^{30}$

Sérgio Ricardo não foi o único a ser chamado para dar explicações sobre suas músicas. Chico Buarque de Hollanda recebeu diversas intimações para prestar esclarecimentos no DOPS da Rua da Relação no Rio de Janeiro. Segundo suas palavras: "Eu conhecia todos lá na Relação. No começo ficava tenso, depois acostumei, reservava sempre algum tempo, caso viesse a ser chamado" ${ }^{31}$ Os motivos para a solicitação de dossiês ou fichas sobre artistas nem sempre eram de natureza política. A cantora Ângela Rô Rô foi obrigada a prestar esclarecimentos sobre um de seus shows, que foi considerado pela DCDP como "nocivo à moral e aos bons costumes tão peculiares ao povo brasileiro". 32

Outro assunto sempre em pauta nos papéis trocados entre a DCDP e as Delegacias de Ordem Política e Social, sobretudo as localizadas no Rio de Janeiro e em São Paulo, foram as operações de apreensão de discos. No ano de 1968 foi realizada uma grande operação deste tipo, que abrangeu todo o território nacional. O disco intitulado Che, gravação de Carlos Sibila, realizado na França e importado para o Brasil, começou a ser vendido. Entretanto, a DCDP pediu com urgência a apreensão do disco e se res-

30 Série “Correspondência oficial”, Subsérie “Informações sigilosas”, ofício n. 393/68, de 16 de outubro de 1968. Caixa 4.

31 BAHIANA, Ana Maria. Nada será como antes: a MPB nos anos 70. Rio de Janeiro: Civilização Brasileira, 1980. p. 33. Entrevista realizada no ano de 1974.

32 Série "Correspondência oficial”, Subsérie "Informações sigilosas”, ofício n. 3974/79, de 14 de outubro de 1979. Caixa 4. 
ponsabilizou por "todas as conseqüências jurídicas que esta medida pudesse acarretar". Para o diretor da DCDP, Aloysio Muhlethaler de Souza, em ofício encaminhado ao Diretor da Delegacia de Ordem Política e Social,

nesta data (4 de setembro de 1968) estamos apurando junto à assessoria jurídica do DPF, a melhor maneira de justificarmos esta apreensão, que torno a salientar, deve ser feita em todo território nacional e de maneira coordenada pelas polícias de cada estado. A gravação faz parte de um plano escuso de infiltração do movimento comunista internacional no Brasil. ${ }^{33}$

As solicitações também eram feitas pelo DOPS, que demandava por uma gama bem variada de informações, que iam desde informações pessoais dos compositores até o pedido de envio das últimas gravações realizadas por eles. ${ }^{34}$

A música, o teatro e o cinema foram atividades constantemente vigiadas e, na maioria das vezes, esse processo era tratado como simples rotina policial. Instrumentos reguladores, como "leis de imprensa" e "classificações etárias", sempre estiveram presentes no cotidiano do brasileiro e largas parcelas da sociedade lhes conferiam legitimidade, pois acreditavam serem estes "normais". ${ }^{35}$ Os censores de diversões públicas consideravam sua atividade legítima e garantida por lei. ${ }^{36}$

Nos anos 1970, a DCDP era bastante conhecida do público, em virtude da obrigatoriedade de exibição nos cinemas, nas TVs e nos teatros do certificado de censura. ${ }^{37}$ Essa notoriedade, aliada ao fato de que a censura de diversões públicas era considerada "normal" por grande parte da população, levou um número considerável de pessoas a escrever cartas

33 Série “Correspondência oficial”, Subsérie “Informações sigilosas”, ofício n. 310/68, de 4 de setembro de 1968. Caixa 4.

34 Série “Correspondência oficial”, Subsérie “Informações sigilosas”, ofícios n. 310/78, n. 785/80 e n. 456/81. Caixa 2 e 4.

35 CARNEIRO, Maria Lúcia Tucci (Org.). Minorias silenciadas: história da censura no Brasil. São Paulo: Edusp, 2002. Neste trabalho pode-se ver a evolução da censura no Brasil desde a colônia.

36 BERG, Creuza. Mecanismo do silêncio: expressões artísticas e censura no regime militar (1964-1985). São Carlos: EdUFSCar, 2002. p. 99.

37 FICO, Carlos. "Prezada Censura": cartas ao regime militar. Topoi. Revista de História. Rio de Janeiro, Programa de Pós-Graduação em História Social da UFRJ, n. 5, p. 251-286. 
endereçadas à Divisão. Mesmo que haja cartas escritas individualmente ou por pequenos grupos, o conjunto da correspondência apresenta uma certa homogeneidade nos enunciados, sugerindo a presença de um mesmo padrão cultural. Além disso, a leitura dessa correspondência nos revela uma mesma temática, já que o tom das cartas, salvo algumas poucas exceções, era sempre o mesmo: uma pessoa que solicitava providências acerca de um material que a ofendeu.

Terezinha Rodrigues, dona de casa, escreveu à Divisão no ano de 1983 para solicitar a "urgente proibição da devassa música Rock da cachorra" ${ }^{38}$ A composição de Léo Jaime, cantada por Eduardo Duseck, sofreu repúdio de mais outras duas cartas, que também solicitavam a proibição. Em uma delas, escrita pela Sociedade Paranaense de Proteção dos Animais, havia cerca de 60 assinaturas:

Vimos por meio desta solicitar a proibição da reprodução em público da música rock da cachorra. A música deste cantor vai contra os princípios cristãos de defesa dos animais, que também sofrem e possuem sentimentos. Além do mais, a música deve ser entendida como uma grande metáfora. Cachorra pode representar a mulher em alguns momentos (...) A música é um panfleto à violência doméstica. ${ }^{39}$

Este tipo de atitude espontânea provinda de setores não militares e não governamentais serviu bem aos propósitos da Divisão, que se utilizou desta situação para argumentar a favor de sua legitimidade.

Embora sob o respaldo da lei e de uma significativa parcela da sociedade civil, os censores de diversões públicas não se sentiam à vontade para afirmar que realizavam uma censura política. A censura política

era tratada de maneira sigilosa e causava desconforto aos censores da DCDP, diferentemente da censura moral, assumida orgulhosamente pela Divisão. ${ }^{40}$

38 Série "Correspondência oficial”, Subsérie "Manifestações da sociedade civil”, carta n. 234, Belo Horizonte, 7 de agosto de 1983. Caixa 4.

39 Série "Correspondência oficial", Subsérie "Manifestações da sociedade civil", carta n. 235, Belém, 7 de agosto de 1983. Caixa 4.

40 FICO, Carlos, op. cit., p. 259. 
Mas a atenção para temas políticos sempre esteve presente na cabeça dos censores, e suas ligações com órgãos de natureza eminentemente política, como as Delegacias de Ordem Político e Social, foram constantes.

É preciso que atentemos para o fato de que a censura praticada pelo regime militar não foi homogênea. É possível distinguir uma série de diferenças entre a censura de diversões públicas e a censura feita à imprensa. Enquanto a primeira foi legal, conhecida do público, a última foi negada pelo regime e imposta por atos revolucionários como o AI-5, por exemplo. A censura feita pela DCDP estava inserida em uma longa tradição de defesa da "moral e dos bons costumes" e já existia havia muitas décadas no Brasil, ${ }^{41}$ legalmente, ao contrário da censura da imprensa,

que foi feita pelos militares envergonhadamente, pois lembrava o velho DIP do Estado Novo e os castelistas moderados tinham horror ao velho órgão.42

Como já vimos, os censores de diversões públicas não se sentiam à vontade para realizar censura de temas políticos (embora o fizessem). Podemos perceber aí a dimensão moral de seu trabalho, ao contrário da censura imposta à imprensa, na qual o que prevaleceu foi a dimensão política.

A melhor maneira de entendermos a presença destas duas dimensões é analisar todo o processo de censura realizado pela DCDP (neste caso estamos nos referindo apenas à censura musical) a partir dos pareceres de seus censores. O processo de análise de uma composição era bastante burocratizado. O compositor ou sua gravadora enviava o trabalho, que era estudado pelos censores da turma de música da Divisão. O número habitual de censores por composição analisada variava entre um e quatro, até 21 de novembro de 1968, quando o artigo 13 da Lei n. 5539, buscando uma atuação mais uniforme, estabeleceu o número de três censores por obra a ser analisada. ${ }^{43}$

41 CARNEIRO, Maria Lúcia Tucci, op. cit.

42 FICO, Carlos. Além do golpe: versões e controvérsias sobre 1964 e a ditadura militar. Rio de Janeiro: Record, 2004. p. 88.

43 Lei 5539/nov. 1968. Modifica dispositivos da Lei 4881-A, de 6 de dezembro de 1965, que dispõe sobre o estatuto do magistério superior e dá outras providências. 
A grande maioria dos vetos foi justificada em nome da preservação dos valores tradicionais da família brasileira. Sob esta tópica circularam os mais variados tópicos, desde a defesa da religião católica até a proibição de assuntos em pauta na época, que foram considerados pela censura como atentatórios à tradição da família brasileira, como, por exemplo, referências ao uso de drogas, ao homossexualismo e à questão do divórcio, muito discutida na década de 1970.

A música Em qualquer lugar, de Fernando Adour e Odair José, foi vetada integralmente no ano de 1973 por causa do fato de supostamente ser

possuidora de uma mensagem negativa e de uma linguagem licenciosa, manifestando prática sexual desviante ao dirigir-se à pessoa amada, o personagem dispõe-se à prática sexual, em quaisquer condições, a fim de agradar ao outro. ${ }^{44}$

A gravadora de Odair José, a Phonogram, sugeriu ao compositor alterações na letra da música a fim de garantir a sua aprovação. Entretanto, a medida não surtiu o efeito esperado. No segundo parecer o veto foi mantido:

\begin{abstract}
A letra musical “Em qualquer lugar”, da autoria de Odair José, examinada em grau de recurso, dada a sua proibição anterior, volta a esta Divisão, com algumas modificações. A alteração foi considerada por nós irrelevante, face a permanência do atentado ao pudor e exaltação ao amor livre. ${ }^{45}$
\end{abstract}

Em meio a um momento no qual ocorreu uma "revolução de costumes” em todo o mundo, as músicas no Brasil eram vetadas apenas por fazerem alusões ao movimento hippie ou ao homossexualismo. O compositor Antonio Carlos Vieira Cariello teve sua música intitulada Anjo vetada porque o censor

44 Série “Censura prévia”, Subsérie “Música”, parecer n. 2931/73, 10 de maio de 1973. Cai-

xa 217.

45 Série “Censura prévia”, Subsérie “Música”, parecer n. 3688/73, 6 de junho de 1973. Caixa

217. 
[Verificou] na letra musical em exame que a mesma continha matéria ofensiva à ordem pública, alusão ao movimento hippie e também ao amor proibido entre pessoas do mesmo sexo, pelo que opinou pela sua não liberação.

O veto também era apresentado como instrumento para aprimorar o gosto, elevar o nível cultural e o padrão moral do povo brasileiro. Composições eram vetadas por serem inadequadas, ofensivas e até mesmo por conterem erros gramaticais e serem consideradas de péssima qualidade musical. Os compositores Antonio Leão Júnior, Paulo Menegazzo e Hielo Bonfim tiveram três de suas cinco músicas enviadas à censura vetadas porque

as mesmas apresentam conotações relativas a tóxicos, desrespeito ao hino nacional e palavras de baixo calão com possível deturpação de significados. ${ }^{46}$

Antonio Lauro, repentista cearense, enviou duas letras de sua autoria para a DCDP porque, segundo ele, "queria cantá-las na Feira de Santana”. Mas os censores foram unânimes em declarar suas músicas "de péssima qualidade musical e repletas de erros gramaticais crassos e por isso opinamos pela sua não liberação" ${ }^{47}$ Em casos como este, os censores acabaram atuando como críticos musicais, além de sua função primeira, que era a de censurar.

Embora na censura musical a dimensão moral estivesse muito mais presente, a dimensão política também foi apresentada como motivo para vetos. Na censura musical ocorreu uma mescla de preocupações morais já antigas na tradição do pensamento brasileiro com as questões concernentes especificamente ao regime militar, como, por exemplo, o comunismo, a luta armada, a defesa da segurança nacional, dentre outras.

Nomes como os de Geraldo Vandré e Chico Buarque tornaram-se conhecidos graças aos seus constantes embates com a censura. Chico

219.

46 Série “Censura prévia”, Subsérie “Música”, parecer n. 232/79, 27 de abril de 1979. Caixa

47 Série “Censura prévia”, Subsérie “Música”, parecer n. 265/80, 24 de agosto de 1980.

Caixa 219. 
Buarque teve por volta de 40 músicas vetadas, metade das quais por causa de alusões a questões políticas. ${ }^{48}$ Os casos desses cantores e compositores foram bem visíveis por causa do relativo sucesso que tinham. Entretanto, existiram muitas outras músicas censuradas por razões político-ideológicas. Embora existisse um mal-estar da parte da DCDP em afirmar categoricamente que realizava uma censura política, em seus pareceres os censores não se sentiram incomodados em dizer que determinada música "fere as normas do regime vigente" ou identificar "mensagem de teor subversivo". ${ }^{9}$

Em 1973, a canção Figa de Guiné, de autoria conjunta de BadenPowell e Paulo Sérgio Pinheiro, foi vetada integralmente. Na apreciação sobre o veto, o censor deixou bem claros seus motivos para tal ato:

A letra musical abaixo discriminada, frontalmente contrária à orientação política vigente no país, bem como pelo seu conteúdo francamente de protesto, entendo como violadas as normas contidas na letras D e G do artigo 41 do Decreto 20.493. Opino pela sua não liberação, sem a possibilidade de grau de recurso. ${ }^{50}$

O caso desta música foi notório, já que o censor proibiu o grau de recurso, tamanha foi a sua indignação. O grau de recurso foi uma medida importada da prática jurídica que possibilitou a compositores e gravadoras recorrerem das decisões da censura. Muitas vezes as letras das músicas eram alteradas (por sugestão ou não do censor) para uma nova tentativa de liberação. O recurso poderia ser utilizado apenas duas vezes e era necessário justificar a sua utilização. A justificativa poderia ser aceita ou não pela censura.

Foi uma prática bastante usual na censura musical a sugestão por parte dos censores de pequenas modificações nas letras para que estas pudessem ser aprovadas. Esta foi uma relação bastante complexa por causa do fato de que o censor, além do poder do veto, passou a ter uma influência

48 WERNECK, Humberto. Chico Buarque: letra e música. São Paulo: Companhia das Letras, 1989. v. 1. p. 137 et seq.

49 Série "Censura prévia”, Subsérie “Música”, parecer n. 3533/72, 22 de julho de 1972. Caixa 217.

50 Série “Censura prévia”, Subsérie “Música”, parecer n. 5240/73, 25 de julho de 1973. Caixa 217. 
particular sobre cada obra, pois fazia sugestões que muitas vezes eram aceitas. Nas palavras do cantor Odair José:

Tínhamos que aceitar as sugestões de Brasília. Sentia meu trabalho mutilado, até porque o censor não era meu amigo para dar "pitaco” no meu trabalho. Mas funcionava assim, porque a gravadora alegava que perdia dinheiro com a não liberação das músicas, porque sem a liberação não tinha gravação e sem gravação não tinha dinheiro no bolso. ${ }^{51}$

No ano de 1978, entrou em vigor o Conselho Superior de Censura (CSC), fruto de uma lei feita em 1968 mas que, em razão do recrudescimento do regime e da promulgação do AI-5 em dezembro de 1968, não pôde ser efetivada. O então ministro da Justiça, Petrônio Portella, com o decreto n. 83.973, de 13 de setembro de 1979, regulamentou os artigos da lei de criação do CSC, que pôde assim ser instalado. Criado pela Lei n. 5.536, de novembro de 1968, o Conselho Superior de Censura foi um órgão ligado diretamente ao Ministério da Justiça. O CSC objetivou tornar a censura das atividades artístico-culturais menos arbitrária e subjetiva. Foi uma espécie de segunda instância, à qual recorreram aqueles que, tendo seu trabalho censurado, não concordavam com o veto. O CSC era dividido entre representantes de organismos governamentais e instituições da sociedade civil..$^{52}$

Com o funcionamento do CSC, a possibilidade de recurso à própria DCDP perdeu parte de sua importância, já que compositores ou gravadoras que não concordavam com os vetos passaram a recorrer diretamente ao Conselho. O Conselho amenizou também as interferências dos censores nas letras musicais, pois os compositores poderiam recorrer a uma outra instância que não a censura, sentindo-se menos obrigados a aceitar sugestões que facilitassem a liberação de suas músicas.

O que podemos perceber nos pareceres é que, depois de 1980, com o total funcionamento do CSC, a grande maioria das músicas vetadas

51 ARAÚJO, Paulo César. Eu não sou cachorro não: música popular cafona e ditadura militar. Rio de Janeiro: Record, 2002. p. 285.

52 ALBIN, Ricardo Cravo. Driblando a censura: de como o cutelo vil incidiu na cultura. Rio de Janeiro: Gryphus, 2002. p. 16. 
eram encaminhadas diretamente ao Conselho. Sabendo desta medida, os censores passaram a fazer bem menos sugestões de alterações nas letras, 0 que não significou, de maneira alguma, um abrandamento da censura, já que os vetos ocorreram de maneira direta e sem a possibilidade de alteração para que a letra pudesse ser liberada, a não ser que a alteração viesse da parte do compositor ou de sua gravadora.

Embora possamos perceber a existência de duas dimensões (moral e política) na censura musical, elas não conviveram separadamente, mas estiveram intimamente relacionadas. A tentativa de manutenção, por parte do regime militar, de uma determinada moralidade foi fruto de um projeto político maior, da construção de uma chamada “utopia autoritária” na qual os militares acreditavam ser "superiores aos civis em questões como patriotismo, conhecimento da realidade brasileira e retidão moral". ${ }^{53}$ A censura, portanto, estava imbuída de uma função dupla, saneadora e disciplinadora, isto é,

a saneadora visava a “curar o organismo social”, extirpandolhe (fisicamente) o câncer do comunismo; a segunda, de base pedagógica, buscava suprir supostas deficiências do povo brasileiro, visto como despreparado e manipulável. ${ }^{54}$

Embora a censura musical nunca tenha tido o objetivo de "extirpar fisicamente o câncer do comunismo", suas tentativas foram no sentido de eliminar a simples menção em letras de músicas da existência de algo que não era do interesse do regime e ao mesmo tempo extrair também das letras a propagação de novos costumes que também não atendiam aos seus interesses, mantendo com isso uma visão de mundo própria e de acordo com os ditames dos militares.

Com base nos relatório anuais da DCDP, podemos perceber outra característica notável na censura musical. Ao contrário do que alguns autores afirmam, ${ }^{55}$ os relatórios indicam uma grande concentração de músicas censuradas no final dos anos 1970 e começo dos anos 1980. Em 1973 fo-

53 D ARAÚJO, Maria Celina et al. (int e org). Visões do golpe: a memória militar sobre 1964. Rio de Janeiro: Relume-Dumará, 1994. p. 9.

54 FICO, Carlos. Op. cit. p. 112. 
ram censuradas 159 letras musicais; em 1976, 198 e, em sua fase final, já no ano de 1980, houve um registro de 458 músicas censuradas. ${ }^{56}$ Nos anos 1980 foram promovidos alguns seminários para atualizar o pessoal que trabalhava com a censura de diversões públicas. Além disso, foram propostas novas diretrizes e projetos de reformulação da legislação. ${ }^{57}$ Estes fatores nos indicam que mesmo em um período considerado de abertura política a censura musical funcionou a pleno vapor. ${ }^{58}$

Esta característica pode ser apontada como mais uma importante diferença entre a censura de diversões públicas e a censura feita à imprensa. Ao contrário da censura à imprensa, a censura de diversões públicas não teve correspondência com o período de maior repressão do regime militar (1968-1973).

Mesmo em meio ao processo de abertura não houve um afrouxamento da censura musical nem um desgaste, como aconteceu com a censura feita à imprensa. Pelo contrário, a DCDP funcionou até o ano de 1988, embora a partir de 1985, com o fim do regime, o número de vetos tenha caído drasticamente. ${ }^{59}$ A DCDP foi finalmente extinta no ano de 1988, quando foi promulgada uma nova Constituição, na qual determinou-se a passagem da censura de diversões públicas para o âmbito do Ministério da Educação, com um caráter apenas classificatório. ${ }^{60}$

55 SOARES, Gláucio Ary Dillon. A censura durante o regime autoritário. Revista Brasileira de Ciências Sociais, v. 4, n. 10, p. 21-43, jun. 1989.

56 Informação da DCDP de 10 de julho de 1980. Série “Correspondência oficial”, subsérie “Informações sigilosas”. Caixa 1.

57 FICO, Carlos. op. cit., p. 265.

58 O período conhecido como abertura iniciou-se com o Governo Geisel (1974-1979) e estendeu-se até o final do Governo Figueiredo (1979-1985).

59 Informação da DCDP de 17 de agosto de 1987. Série “Correspondência oficial”, subsérie “Informações sigilosas”. Caixa 1. Comparamos esta lista de músicas censuradas com aquelas expedidas em anos anteriores.

60 Constituição Federativa do Brasil, artigo 18, capítulo II, promulgada em 5 de outubro de 1988. Dispõe sobre a organização do Estado, mais especificamente da União, e dá outras providências. 